\section{Hiring Preferences of Nurseries and Greenhouses in U.S. Southern States}

\author{
Benedict C. Posadas ${ }^{1}$, Patricia R. Knight, Christine E.H. Coker, \\ Randal Y. Coker, and Scott A. Langlois
}

\begin{abstract}
ADDITIONAL INDEX WORDS. hiring decisions, regional socioeconomic survey, worker characteristics

SUMMARY. This work describes workers' socioeconomic characteristics and evaluates the determinants of workers hiring decisions among 215 randomly selected wholesale nurseries and greenhouses located in eight selected southern states in the United States. The participating nurseries and greenhouses employed on average 5.40 permanent workers per horticulture operation or 2.27 permanent workers per acre under cultivation. Participating nurseries and greenhouses hired an average 2.38 part-time workers per horticulture operation or 0.80 part-time workers per acre placed under production. Empirical models were estimated to determine the significant factors affecting hiring decisions by this industry. Hiring decision models covered age groups, racial backgrounds, formal education levels, and gender. Analysis of the decision-making process involving the employment of hired workers among the participating wholesale nurseries and greenhouses provided insights into the hiring decisions in the industry. The hiring decisions by demographic characteristics serve as benchmarks for assessing impacts of regulations affecting the industry in the near future. About $1.9 \%$ of all the establishments employed more than 50 permanent and part-time workers and $1.4 \%$ employed more than 50 permanent workers.
\end{abstract}

$\mathrm{H}$ ired farmworkers make up a third of the total agricultural labor force and are critical to U.S. agricultural production, particularly for labor-intensive sectors such as fruit and vegetable farms (Kandel, 2008). Regelbrugge (2007) described the nursery and greenhouse industry as one of the fastest-growing sectors of U.S. agriculture, and is inherently labor intensive with $\approx 40 \%$ of production costs consisting of labor costs (Kandel, 2008; Mathers et al., 2010). The most recent estimates by Hodges et al. (2011) showed that the total economic impact of the U.S. green industry reached $\$ 175.26$ billion representing $\approx 0.76 \%$ of the national gross domestic product in 2007. The U.S. green industry generated a total employment impact of 1.95

Mississippi State University, Coastal Research and Extension Center, 1815 Popps Ferry Road, Biloxi, MS 39532

This work was funded in part by the National Institute of Food and Agriculture through the Current Research Information System project number MIS211110 in collaboration with the Multistate Project Number S-1051 or the Green Industry Research Consortium.

The authors would like to express their sincerest gratitude to the nursery and greenhouse operators and managers who participated in the socioeconomic survey from Dec. 2003 to Nov. 2009.

${ }^{1}$ Corresponding author. E-mail: benp@ext.msstate.edu. million jobs, labor earnings impact of $\$ 53.16$ billion, and $\$ 107.16$ billion in value-added impact.

Continuous improvements in worker's skills and their year-round availability are necessary to sustain the robust growth in the nursery and greenhouse industry. Most of the jobs in the industry require large amounts of stooping, lifting of heavy containers, and exposure to chemicals, dust, and plant materials (Bureau of Labor Statistics, 2012). These labor-intensive jobs are relatively low paying, with $\$ 8.98$ per hour or $\$ 18,670$ per year $\left(\mathrm{O}^{*}\right.$ Net Online, 2013), making it difficult for managers to compete for and retain workers in currently tight domestic labor markets. Many commercial operations have employed immigrant labor, which is mostly less skilled, to meet their rising labor requirements. The nursery migrant workforce are employed, on average 6 months, and most stayed for 10 months (Mathers et al., 2010).

A regional socioeconomic survey of randomly selected wholesale nurseries and greenhouses was conducted in eight selected U.S. southern states as a part of a research program undertaken by the Mississippi Agricultural and Forestry Experiment Station median wages in 2012 amounting to and the U.S. Department of Labor entitled "Enhancing Labor Performance of the Green Industry in the Gulf South." The socioeconomic survey consisted of eight parts, namely workers' demographic characteristics, nursery characteristics, nursery automation, greenhouse automation, labor and capital markets, pesticide and chemicals, working conditions, and respondents' characteristics (Posadas et al., 2004). The overall goals of the regional socioeconomic survey were to develop a socioeconomic profile of horticulture workers and to evaluate the impact of automation on their employment, earnings, safety, skill levels, and retention rates.

The scope of this work, however, is limited to the socioeconomic aspects of the decisions involved in the hiring of permanent and part-time workers in the industry. Earlier publications using the above-mentioned databases collected from Louisiana, Mississippi, and Alabama covered the socioeconomic characteristics of workers and working conditions (Posadas et al., 2010a), operational characteristics (Posadas et al., 2010b), socioeconomic determinants of technology adoption (Posadas et al., 2005), and socioeconomic impacts of mechanization and automation (Posadas et al., 2008). Additional publications covering all the participating nurseries and greenhouses in the eight U.S. southern states included current mechanization systems (Coker et al., 2010) and socioeconomic impacts of mechanization and automation (Posadas, 2012).

Understanding the socioeconomic aspects of the hiring preferences and employment of workers within the nursery and greenhouse industry will provide nursery and greenhouse operators, managers, and owners and horticulture researchers and extension specialists, better insights into the underlying human dimensions of the horticultural industry. The hiring decisions by demographic characteristics serve as benchmarks for assessing impacts of regulations affecting the industry in the near future. Holt et al. (1970) suggested that agricultural hired labor must become a major component of the educational, research, and extension mission of agricultural colleges. The overall goals of this work are to determine the socioeconomic characteristics of workers and evaluate the determinants of horticultural firms 
hiring decisions. This work aims to achieve the following specific objectives: 1) to determine the socioeconomic characteristics of workers of randomly selected wholesale nurseries and greenhouses in the eight selected U.S. southern states, and 2) to evaluate the determinants of workers hiring decisions across different socioeconomic characteristics by randomly selected wholesale nurseries and greenhouses in the eight selected U.S. southern states.

\section{Materials and methods}

SOCIOECONOMIC DATA ANALYSIS. The socioeconomic data consisted of variables dealing with labor, technical, and economic information about the nurseries and greenhouses in the eight U.S. southern states. The workers' demographic characteristics included race, age, gender, and formal education completed. The demographic characteristics were measured in terms of the number and percent of workers who belonged to each of the categories. The operational characteristics of the participating nurseries and greenhouses included, but were not limited to, labor usage, growing area, type of operations, annual gross sales, availability of labor and capital. Labor usage was measured in terms of the number of permanent and part-time workers. The growing area was measured by the total number of acres available, and number and percent of acres used in production. The availability of labor, long-term capital, or operating capital was measured in terms of the responses to the question "How would you describe the availability of labor, long-term capital or operating capital for the nursery industry?" The possible responses were highly unavailable, unavailable, available, and highly available.

The types of horticultural operations included nursery-only, greenhouse-only, and mixed-type operations. Mixed-type operations are horticultural farms that operate both nurseries and greenhouses. Dummy variables representing nursery-only and greenhouse-only operations were included in the models to differentiate them from mixed-type operations.

The average level of automation or mechanization of all the identified major tasks performed by workers in each nursery or greenhouse operation was used in the empirical models instead of the specific level of automation or mechanization of each individual task identified in the survey (Posadas, 2012; Posadas et al., 2008). The average level of mechanization or automation of all the identified major tasks performed by workers in each nursery or greenhouse was computed as follows: aveloam $=\sum_{1}^{n} \operatorname{loam} / n$, where loam is the level of mechanization or automation in each specific task performed by workers in each nursery or greenhouse (percent) and $n$ is the number of tasks performed by workers in each nursery or greenhouse.

Large employers tend to pay higher wages and offer better fringe benefits, working conditions, and upward mobility because they may have greater resources and stability (Mitra, 2003). The size of the nursery and greenhouse operations was measured by the reported annual gross sales. The dummy variables representing the various sizes of the nursery and greenhouse operations were based on the annual gross sales reported by the wholesale growers. The categories of annual gross sales included are the following: less than $\$ 250,000 ; \$ 250,000$ to less than $\$ 500,000 ; \$ 500,000$ to less than $\$ 1,000,000 ; \$ 1,000,000$ to less than $\$ 2,000,000$; and $\$ 2,000,000$ and above.

The means of the demographic characteristics of the workers in wholesale nurseries and greenhouses were estimated and compared by using the analysis of variance (ANOVA) procedure and Scheffe multiple-comparison test in Stata 12 (StataCorp, College Station, Texas). To determine the significant factors influencing hiring decisions by wholesale nurseries and greenhouses, the empirical decision models defined by Eq. [1-4] were estimated by using the ordinary least squares regression (OLS) procedure. The OLS models were estimated by the robust variance procedure in Stata 12, as suggested by Rogers (1993) and Williams (2000). Accurate assessments of the sample-to-sample variability of the parameter estimates are achieved with the use of the robust variance procedure. The marginal impacts of the independent variables on the hiring decisions made by wholesale nurseries and greenhouses were measured by using the margins procedure in Stata 12.

EMPIRICAL HIRING DECISION MODELs. Recent studies on preferences for hired workers by horticultural establishments have provided guidance in modeling the empirical hiring decisions of nurseries and greenhouses. However, it had been noted several decades ago that the quality and quantity of hired labor demanded by agricultural establishments are being influenced by technical and managerial innovations taking place in the industry (Holt et al., 1970).

Bellenger et al. (2008) concluded that Alabama producers' decisions to hire migrant workers raised wages within the green industry and producers' concerns regarding government regulations and lack of professionalism may have some influence on their decisions to hire migrant workers. Both the number of full-time equivalent workers and the number of man-hours employed by the nurseries and greenhouses in eight U.S. southern states were directly related to the number of acres in production and the type of operation (Posadas, 2012). There are substantial costs to migration and employers must offer a large earnings premium to induce workers to move to their jobs (Perloff et al., 1998).

The retention of seasonal farmworkers depends on decisions by the workers and the employers. Gabbard and Perloff (1997) suggested that employers are more likely to rehire prime age, experienced, foreign-born workers and that the probability that a worker returns is increased by spending the last dollar of compensation on benefits or improving working conditions rather than on higher wages. Posadas (2012) observed exceedingly high workers' retention rates among the participating wholesale operations with no significant variations among various types of operations.

In Oregon nurseries, Buccola et al. (2011) reported that increases in the work hours demanded by $10 \%$ led to less than $2 \%$ rise in the demanded wage rate. In Alabama, Bellenger et al. (2008) observed that seasonal parttime and full-time wages were positively impacted by the percentage of the labor force hired by the horticulture establishments that were composed of migrant workers.

\section{Workers by racial background}

The decisions to hire workers across age groups, racial backgrounds, formal education, and gender were evaluated by using a variant of the 
full-time equivalent (FTE) empirical model described by Posadas et al. (2008) and Posadas (2012). These hiring decisions made by nurseries and greenhouses were measured in terms of the number of workers employed who belonged to the different age groups, racial backgrounds, formal education, and gender.

The hiring-by-race null hypothesis was that nurseries and greenhouses have no preferences on hiring workers of different racial backgrounds. The empirical model used to evaluate hiring decisions across racial groups was as follows:

$$
\begin{aligned}
\text { workrb }_{i}= & \mathrm{b}_{\mathrm{o}}+\mathrm{b}_{1} \text { defwager } \\
& +\mathrm{b}_{2} \text { aveloam }+\mathrm{b}_{3} \text { nurtype } \\
& +\mathrm{b}_{4} \text { busiyear }+\mathrm{b}_{5} \text { date } \\
& +\mathrm{b}_{6} \text { salesgroup }+\mathrm{b}_{7} \text { acreprod } \\
& +\mathrm{b}_{8} \text { peracuse }+\mathrm{b}_{9} \text { laboravail } \\
& +\mathrm{b}_{10} \text { ltermcap }+\mathrm{b}_{11} \text { opercap } \\
& +\mathrm{b}_{12} \text { soleprop }+\mathrm{e},
\end{aligned}
$$

where workrb $_{i}$ is workers with $i$ th racial background (number per operation), $\mathrm{b}_{\mathrm{o}}$ constant term, $\mathrm{b}_{i}$ regression coefficients, defwager deflated gross wage rate (dollars per hour in constant 2009 prices), aveloam average level of mechanization (percent), nurtype type of horticultural operation, busiyear period since establishment (years), date interview date, salesgroup annual gross sales bracket (dollars), acreprod area used in production (acres), peracuse acreage used in production (percent), laboravail dummy variable representing perception of labor availability (available or highly available $=1$, other $=0$ ), ltermcap dummy variable representing perception of long-term capital availability (available or highly available $=$ 1 , other $=0$ ), opercap dummy variable representing perception of operating capital availability (available or highly available $=1$, other $=0$ ), soleprop dummy variable representing sole proprietorship (sole proprietorship $=1$, other $=0$ ), and e error term.

\section{Workers by age groups}

The hiring-by-age null hypothesis was that nurseries and greenhouses have no preference on hiring workers of different age groups. The empirical model used to evaluate hiring decisions across age groups was as follows: workag $_{i}=\mathrm{b}_{\mathrm{o}}+\mathrm{b}_{1}$ defwager

$$
\begin{aligned}
& +b_{2} \text { aveloam }+b_{3} \text { nurtype } \\
& +b_{4} \text { busiyear }+b_{5} \text { date } \\
& +b_{6} \text { salesgroup }+b_{7} \text { acreprod } \\
& +b_{8} \text { peracuse }+b_{9} \text { laboravail } \\
& +b_{10} \text { ltermcap }+b_{11} \text { opercap } \\
& +b_{12} \text { soleprop }+\mathrm{e},
\end{aligned}
$$

where workag $_{i}$ is workers in $i$ th age group (number per operation) and the rest as defined in Eq. [1].

\section{Workers by formal educational attainment}

As suggested by Jones (2001), there is a correlation between worker productivity and level of education in specific manufacturing jobs. Perhaps the same holds true in the unique field of nursery and greenhouse production. In addition to the potential for increased productivity, there may be a correlation between this education level and the ease at which new equipment and mechanization are integrated into an operation. Bartel and Lichtenberg (1987) determined that workers with a higher level of education have an advantage over a less educated workforce in terms of learning and implementing new technologies. Understanding this relationship may influence the decision-making process for green industry owners contemplating capital purchases. The hiring-by-formal-education null hypothesis was that nurseries and greenhouses have no preference in hiring workers of different educational attainment. The empirical model used to evaluate hiring decisions based on formal educational attainment was as follows:

$$
\begin{aligned}
\text { workfea }_{i} & =\mathrm{b}_{\mathrm{o}}+\mathrm{b}_{1} \text { defwager } \\
& +\mathrm{b}_{2} \text { aveloam }+\mathrm{b}_{3} \text { nurtype } \\
& +\mathrm{b}_{4} \text { busiyear }+\mathrm{b}_{5} \text { date } \\
& +\mathrm{b}_{6} \text { salesgroup }+\mathrm{b}_{7} \text { acreprod } \\
& +\mathrm{b}_{8} \text { peracuse }+\mathrm{b}_{9} \text { laboravail } \\
& +\mathrm{b}_{10} \text { ltermcap }+\mathrm{b}_{11} \text { opercap } \\
& +\mathrm{b}_{12} \text { soleprop }+\mathrm{e},
\end{aligned}
$$

where workfea ${ }_{i}$ is workers who completed $i$ th formal educational attainment and the rest as defined in Eq. [1].

\section{Workers by gender}

Mitra (2003) analyzed the allocation of male and female professionals in large establishments and the extent of gender wage differentials across small, medium, and large establishments. Many of the female workers in the green industry are placed in positions that include propagation, pruning, and staking/tying. The hiring-by-gender null hypothesis was that nurseries and greenhouses have no preferences on hiring workers of different gender. The empirical model used to evaluate hiring decisions across gender groups was as follows:

$$
\begin{aligned}
\text { workg }_{i}= & \mathrm{b}_{\mathrm{o}}+\mathrm{b}_{1} \text { defwager } \\
& +\mathrm{b}_{2} \text { aveloam }+\mathrm{b}_{3} \text { nurtype } \\
& +\mathrm{b}_{4} \text { busiyear }+\mathrm{b}_{5} \text { date } \\
& +\mathrm{b}_{6} \text { salesgroup }+\mathrm{b}_{7} \text { acreprod } \\
& +\mathrm{b}_{8} \text { peracuse }+\mathrm{b}_{9} \text { laboravail } \\
& +\mathrm{b}_{10} \text { ltermcap }+\mathrm{b}_{11} \text { opercap } \\
& +\mathrm{b}_{12} \text { soleprop }+\mathrm{e},
\end{aligned}
$$

where workg $g_{i}$ is workers who belonged to the $i$ th gender and the rest as defined in Eq. [1].

Primary data collection. Face-to-face interviews with randomly selected wholesale nurseries and greenhouses in eight U.S. southern states (Mississippi, Alabama, Louisiana, Florida, Tennessee, South Carolina, North Carolina, and Georgia) were conducted between Dec. 2003 and Nov. 2009 . This length of time was required due to the distance traveled to complete the surveys, the availability of the growers to meet one-on-one with the survey administrator, and the occurrence of major natural disasters that affected the growers and the project staff. Official lists of certified nurseries were retrieved from the Mississippi Department of Agriculture and Commerce (2003), Alabama Department of Agriculture and Industries (2004), Louisiana Department of Agriculture and Forestry (2003), South Carolina Department of Agriculture (2006), Florida Department of Agriculture and Consumer Services (2005), North Carolina Department of Agriculture and Consumer Services (2008), Georgia Department of Agriculture (2007), and Tennessee Nursery and Landscape Association (2006).

The certified lists of nurseries and greenhouses were compiled from 
the official lists retrieved from the eight selected states. Only wholesale growers operating throughout the seven states, and northern Florida, were included in the selection of survey participants. In northern Florida, nurseries were randomly selected from the listing using only the nurseries in counties from Alachua County and north. The wholesale growers in each state included in the survey were identified and numbered from one to $N$. Using Excel (Office 2003; Microsoft Corp, Redmond, WA), 50 random integers were individually generated from one to $N$, where $N$ is the number of wholesale growers in each state.

Individual letters were sent to the 50 randomly selected nurseries and greenhouses in each state in advance. They were asked to return a prepaid postcard indicating their willingness to participate in the survey. Those nurseries indicating a willingness to participate were then contacted by phone, and interviews scheduled. All personal interviews were conducted by the research associate hired for this purpose by the Mississippi State UniversityCoastal Research and Extension Center. The respondents to the survey were the owners or operators of the selected nurseries and greenhouses. A total of 215 personal interviews were completed with wholesale nurseries $(N=88)$, greenhouses, $(N=52)$, and mixed nursery/greenhouse operations $(N=75)$ in Mississippi (32), Louisiana (29), Alabama (26), Florida (27), Tennessee (17), South Carolina (30), North Carolina (30), and Georgia (24).

\section{Results and discussion}

Number OF WORKERs. The number of family and hired farmworkers on U.S. farms in 2006 averaged 0.98 and 0.48 workers, respectively (Kandel, 2008). The share of labor costs to total cash expenses among crops and livestock farms in 2006 was less than $15 \%$ as compared with about $40 \%$ among fruit, vegetable, and nursery farms (Kandel, 2008).

The number of permanent workers employed by the nurseries and greenhouses was measured by the number of workers hired per operation and per acre under cultivation. The participating nursery or greenhouse establishments employed an average 5.40 permanent workers per operation or 2.27 workers per acre under cultivation. Table 1 shows that the number of permanent workers per operation was significantly lower among smaller operations with annual gross sales below $\$ 1,000,000$ as compared with the larger operations. The average number of permanent workers per acre was numerically higher among operations with annual sales below $\$ 1,000,000$ in contrast with the larger operations.

The number of part-time workers employed by the nurseries and greenhouses was calculated by the average number of workers hired during peak season per horticultural operation and per acre placed under cultivation. The participating nursery or greenhouse operations employed an average 2.38 part-time workers per horticulture operation or 0.80 part-time workers per acre placed under production during the entire period under consideration (Table 1). Larger nurseries and greenhouses hired more part-time workers than the small operations. The average number of part-time workers per acre was not significantly different among different-size operations.

The total number of workers varied significantly across annual gross sales. Larger horticultural operations tend to hire more workers, especially among those with annual gross sales above $\$ 2,000,000$. About $1.9 \%$ of all the participating horticultural establishments employed more than 50 permanent and part-time workers. In terms of permanent workers only, $\approx 1.4 \%$ of all the participating nurseries and greenhouses employed more than 50 permanent workers.

RACIAL BACKGROUND OF WORKERS. Recent national estimates showed that the percent distribution of hired workers among U.S. farms by race are as follows: White (41\%), African-Americans (4\%), American Indian ( $8 \%)$, Asian $(<1 \%)$, Native Hawaiian $(<1 \%)$, and other $(47 \%)$ (Kandel, 2008). Survey results indicated that the percent of workers with Caucasian background averaged 65\% among the participating nursery or greenhouse operations (Table 2). The second group most highly employed was those of Hispanic origin averaging $22 \%$ of the workers employed by horticultural operations that joined the survey. About $11 \%$ of the workers employed by the nurseries and greenhouses that responded to the survey were African-Americans. The remaining workers employed by the horticultural

Table 1. Number of workers employed by randomly selected wholesale nurseries and greenhouses located in eight selected U.S. southern states, which participated in a socioeconomic survey from Dec. 2003 to Nov. 2009 by annual gross sales.

\begin{tabular}{|c|c|c|c|c|c|c|c|}
\hline Variable code & $\begin{array}{c}\text { Variable } \\
\text { description }\end{array}$ & $\begin{array}{c}\text { Sales } \\
\text { less than } \\
\$ 250,000 \\
\end{array}$ & $\begin{array}{c}\text { Sales } \\
\$ 250,000- \\
\$ 499,999\end{array}$ & $\begin{array}{c}\text { Sales } \\
\$ 500,000- \\
\$ 999,999\end{array}$ & $\begin{array}{c}\text { Sales } \\
\$ 1,000,000- \\
\$ 1,999,999\end{array}$ & $\begin{array}{c}\text { Sales } \\
\$ 2,000,000 \\
\text { and above }\end{array}$ & $\begin{array}{c}\text { All } \\
\text { operations }\end{array}$ \\
\hline Workperm & $\begin{array}{l}\text { Permanent workers } \\
\quad(\text { no./operation })^{z}\end{array}$ & $1.73 \mathrm{a}^{\mathrm{y}}$ & $4.34 \mathrm{~b}$ & $6.36 \mathrm{~b}$ & $9.94 \mathrm{c}$ & $35.91 \mathrm{~d}$ & 5.40 \\
\hline Workpart & $\begin{array}{l}\text { Part-time workers } \\
\quad(\text { no./operation })^{\mathrm{z}}\end{array}$ & $0.75 \mathrm{a}$ & $1.56 \mathrm{~b}$ & $4.13 \mathrm{~b}$ & $9.36 \mathrm{c}$ & $7.08 \mathrm{c}$ & 2.38 \\
\hline Anpw & $\begin{array}{l}\text { Permanent workers } \\
(\text { no./acre })^{x, w}\end{array}$ & $2.57 \mathrm{a}$ & $2.67 \mathrm{a}$ & $2.22 \mathrm{a}$ & $0.73 \mathrm{a}$ & $0.52 \mathrm{a}$ & 2.27 \\
\hline Anptw & $\begin{array}{l}\text { Part-time workers } \\
(\text { no. } / \text { acre })^{\mathrm{x}, \mathrm{v}}\end{array}$ & $0.84 \mathrm{a}$ & $0.57 \mathrm{a}$ & $1.35 \mathrm{a}$ & $0.78 \mathrm{a}$ & $0.16 \mathrm{a}$ & 0.80 \\
\hline
\end{tabular}

${ }^{2}$ Significantly different by annual gross sales at $P \leq 0.001$ using analysis of variance (ANOVA).

Values in the same row with different letters are significantly different by annual gross sales at $P \leq 0.05$ using Scheffe multiple-comparison test.

${ }^{x} 1$ worker $/$ acre $=2.4711$ workers $/$ ha .

"Significantly different by annual gross sales at $P \leq 0.05$ using ANOVA.

Not significantly different by annual gross sales at $P \leq 0.05$ using ANOVA. 
operations were Asians (<1\%) and $\mathrm{Na}$ tive Americans $(<1 \%)$.

Regression results showed that the hiring of Caucasian, AfricanAmericans, and Hispanic workers were significantly explained by the variables included in the models. The empirical model for "workers with Caucasian background" explained $75.4 \%$ of the variations in hiring decisions (Table 3 ). The regression results for the "workers with Hispanic background" supported $64.7 \%$ of the differences in the hiring decisions. The results of the "workers with African-American background" were not included because only $23.4 \%$ of the deviations in the hiring decisions were accounted for by the model.

The number of Caucasian workers employed by the participating establishments was significantly affected by the type of operation, interview date, annual gross sales, acreage, and availability of operating capital (Table 3 ). Neutral effects on the hiring of Caucasian workers were observed from the gross wage rate, level of mechanization, period since establishment, availability of labor and long-term capital, and sole proprietorship.

The number of Hispanic workers hired by the nurseries and greenhouses was strongly influenced by the period since establishment, interview date, annual gross sales, and acreage (Table 3 ). There were no significant effects displayed by the gross wage rate, mechanization, type of operation, acreage, and availability of labor and capital.

The type of operation played a significant influence in hiring decisions among Caucasian workers. The nurseryonly and greenhouse-only operations hired fewer Caucasian workers than the mixed-nursery-greenhouse operations (Table 3). There were 88 nursery-only operations $(40.9 \%$ of the total number of participating establishments), 52 greenhouse-only operations $(24.1 \%)$, and 75 mixed-nursery-greenhouse operations $(34.9 \%)$.

The participating establishments had been in business, on average, 24.6 years since establishment (Table 4 ). The period since establishment played a significant influence in hiring decisions by racial backgrounds. Older establishments tend to hire relatively fewer Hispanic workers (Table 3).

The date of interview seemed to have some significant effects on the hiring decisions. Over time, relatively more Caucasian and Hispanic workers were employed by the participating establishments (Table 3).

About $55 \%$ of the nurseries and greenhouses had annual gross sales below $\$ 250,000$ (Table 4 ). The annual gross sales of the participating nurseries and greenhouses exerted a critical role in the hiring of workers. Larger operations with higher annual gross sales engaged more workers with both Caucasian and Hispanic backgrounds (Table 3 ). However, larger operations have a tendency to hire relatively more Hispanic than Caucasian workers.

Acreage increased significantly among operations with annual gross above $\$ 1,000,000$ (Table 4 ). Acreage had limited but significant impact on hiring decisions. Those operations with more acreage under production employed fewer Caucasian workers (Table 3). Establishments with more of their acreage already in production tend to employ more Hispanic workers.

The perception of the availability of operating capital was significantly different among the different sizes of nurseries and greenhouses (Table 4). About $66 \%$ of the participants considered operating capital to be available or highly available between 2004 and 2009. The perception of wider availability of operating capital led nurseries and greenhouses to hire more workers with Caucasian backgrounds (Table 3 ).

Age COMPOSITION OF WORKERS. Recent data on the overall age distribution of hired workers in U.S. farms showed the following cohorts: 14-24 years old $(31 \%), 25-34$ years old $(30 \%), 35-44$ years old $(20 \%), 45-$ 54 years old (12\%), and 55 years old and above (7\%) (Kandel, 2008). The socioeconomic survey results showed that workers 18-29 years old (22\%) and 30-39 years old (19\%) comprised $41 \%$ of the entire workforce of participating operations (Table 5). Workers who belonged to the 40 - to 49-year-old group (29\%) and 50- to 59 -year-old group (21\%) added 50\% more workers to the total labor force. The remaining 9\% of the workers were 60 years old and above.

The empirical results indicated that the decisions involving the employment of workers belonging to the different age groups were significantly driven by the variables included in the models. The independent variables

Table 2. Racial background of workers employed by randomly selected wholesale nurseries and greenhouses located in eight selected U.S. southern states, which participated in a socioeconomic survey from Dec. 2003 to Nov. 2009 by annual gross sales.

\begin{tabular}{|c|c|c|c|c|c|c|c|}
\hline Variable code & Variable description & $\begin{array}{c}\text { Sales } \\
\text { less than } \\
\$ 250,000\end{array}$ & $\begin{array}{c}\text { Sales } \\
\$ 250,000- \\
\$ 499,999\end{array}$ & $\begin{array}{c}\text { Sales } \\
\$ 500,000- \\
\$ 999,999\end{array}$ & $\begin{array}{c}\text { Sales } \\
\$ 1,000,000- \\
\$ 1,999,999\end{array}$ & $\begin{array}{c}\text { Sales } \\
\$ 2,000,000 \\
\text { and above }\end{array}$ & $\begin{array}{c}\text { All } \\
\text { operations }\end{array}$ \\
\hline Workwhite & $\begin{array}{l}\text { Workers with Caucasian } \\
\text { background (no./operation })^{z}\end{array}$ & $1.74 \mathrm{a}^{\mathrm{y}}$ & $3.46 \mathrm{~b}$ & $4.36 \mathrm{~b}$ & $6.94 \mathrm{c}$ & $16.67 \mathrm{~d}$ & 3.69 \\
\hline Workaa & $\begin{array}{l}\text { Workers with African-American } \\
\text { background (no./operation })^{z}\end{array}$ & $0.40 \mathrm{a}$ & $0.73 \mathrm{a}$ & $1.22 \mathrm{a}$ & $5.00 \mathrm{~b}$ & $3.08 \mathrm{~b}$ & 1.12 \\
\hline Pwwhite & $\begin{array}{l}\text { Workers with Caucasian } \\
\text { background }(\%)^{\mathrm{z}}\end{array}$ & $0.75 \mathrm{a}$ & $0.65 \mathrm{a}$ & $0.44 \mathrm{~b}$ & $0.41 \mathrm{~b}$ & $0.39 \mathrm{~b}$ & 0.65 \\
\hline Pwaa & $\begin{array}{l}\text { Workers with African-American } \\
\text { background }(\%)^{\mathrm{x}}\end{array}$ & $0.11 \mathrm{a}$ & $0.09 \mathrm{a}$ & $0.11 \mathrm{a}$ & $0.13 \mathrm{a}$ & $0.09 \mathrm{a}$ & 0.11 \\
\hline Pwhisp & $\begin{array}{l}\text { Workers with Hispanic } \\
\text { background }(\%)^{\mathrm{z}}\end{array}$ & $0.10 \mathrm{a}$ & $0.25 \mathrm{~b}$ & $0.42 \mathrm{bc}$ & $0.43 \mathrm{bc}$ & $0.50 \mathrm{c}$ & 0.22 \\
\hline
\end{tabular}

${ }^{z}$ Significantly different by annual gross sales at $P \leq 0.001$ using analysis of variance (ANOVA).

Values in the same row with different letters are significantly different by annual gross sales at $P \leq 0.05$ using Scheffe multiple-comparison test.

${ }^{x}$ Not significantly different by annual gross sales at $P \leq 0.05$ using ANOVA. 
Tables 3. Factors influencing the decisions to hire workers in nurseries and greenhouses by racial backgrounds. The multiple linear regressions used data collected from the socioeconomic survey of randomly selected wholesale nurseries and greenhouses located in eight selected U.S. southern states from Dec. 2003 to Nov. 2009.

\begin{tabular}{|c|c|c|c|c|}
\hline \multirow[b]{2}{*}{ Independent variable } & \multicolumn{2}{|c|}{$\begin{array}{c}\text { Workers with Caucasian } \\
\text { background (no./operation) }\end{array}$} & \multicolumn{2}{|c|}{$\begin{array}{c}\text { Workers with Hispanic } \\
\text { background (no./operation) }\end{array}$} \\
\hline & Coefficient & $\mathrm{SE}^{\mathrm{Z}}$ & Coefficient & SE \\
\hline Constant term & $-30.614^{* *}$ & 11.264 & $-57.592 *$ & 24.070 \\
\hline Deflated gross wage rate $(\$ / \mathrm{h})$ & $0.376 \mathrm{NS}$ & 0.193 & $-0.226 \mathrm{NS}$ & 0.463 \\
\hline Average level of mechanization (\%) & $0.009 \mathrm{NS}$ & 0.016 & $-0.047 \mathrm{NS}$ & 0.035 \\
\hline Nursery-only operation & $-1.876^{* *}$ & 0.645 & $-0.487 \mathrm{NS}$ & 0.904 \\
\hline Interview date & $0.001^{*}$ & 0.000 & $0.001^{*}$ & 0.000 \\
\hline Annual sales $\$ 250,000-\$ 499,999$ & $1.390 * * *$ & 0.384 & $2.007 * *$ & 0.668 \\
\hline Annual sales $\$ 500,000-\$ 999,999$ & $1.157 \mathrm{NS}$ & 0.795 & $5.277 * * *$ & 1.098 \\
\hline Annual sales $\$ 1,000,000-\$ 1,999,999$ & $5.447 * * *$ & 0.859 & $7.419 * * *$ & 1.470 \\
\hline Annual sales $\$ 2,000,000$ and above & $17.398 * * *$ & 2.760 & $23.174 * * *$ & 5.750 \\
\hline Acreage under production (acres) ${ }^{\mathrm{y}}$ & $-0.032^{*}$ & 0.012 & $0.005 \mathrm{NS}$ & 0.017 \\
\hline Availability of operating capital & $2.001 * *$ & 0.579 & $0.034 \mathrm{NS}$ & 0.807 \\
\hline Sole proprietorship & $0.399 \mathrm{NS}$ & 0.426 & $-0.987 \mathrm{NS}$ & 0.613 \\
\hline Included nurseries and greenhouses (no.) & 173 & & 174 & \\
\hline R-squared & 0.754 & & 0.647 & \\
\hline F statistic & $13.710 * * *$ & & $7.730 * * *$ & \\
\hline
\end{tabular}

${ }^{2}$ Robust SE (accurate assessments of the sample-to-sample variability of the parameter estimates are achieved with the use of the robust variance procedure).

${ }^{y} 1$ acre $=0.4047$ ha.

${ }^{*},{ }^{* *},{ }^{* *}$ Statistically significant at $P \leq 0.05,0.01$, or 0.001 using $\mathrm{T}$ value or $\mathrm{F}$ statistic; ${ }^{\mathrm{N}}$ Not statistically significant at $P \leq 0.05$ using $\mathrm{T}$ value or $\mathrm{F}$ statistic.

Table 4. Selected operational characteristics of randomly selected wholesale nurseries and greenhouses located in eight selected U.S. southern states, which participated in a socioeconomic survey from Dec. 2003 to Nov. 2009 by annual gross sales.

\begin{tabular}{|c|c|c|c|c|c|c|c|}
\hline Variable code & Variable description & $\begin{array}{c}\text { Sales } \\
\text { less than } \\
\$ 250,000\end{array}$ & $\begin{array}{c}\text { Sales } \\
\$ 250,000- \\
\$ 499,999 \\
\end{array}$ & $\begin{array}{c}\text { Sales } \\
\$ 500,000- \\
\$ 999,999 \\
\end{array}$ & $\begin{array}{c}\text { Sales } \\
\$ 1,000,000- \\
\$ 1,999,999\end{array}$ & $\begin{array}{c}\text { Sales } \\
\$ 2,000,000 \\
\text { and above }\end{array}$ & $\begin{array}{c}\text { All } \\
\text { operations } \\
\end{array}$ \\
\hline Defwager & $\begin{array}{l}\text { Deflated gross wage rate }(\$ / h \\
\text { in constant } 2009 \text { prices })^{\mathrm{z}}\end{array}$ & $8.40 \mathrm{a}^{\mathrm{y}}$ & $9.10 \mathrm{a}$ & $8.38 \mathrm{ac}$ & $9.05 \mathrm{a}$ & $10.32 \mathrm{~b}$ & 8.76 \\
\hline Acreprod & Acreage used in production $(\text { acres })^{\mathrm{z}}$ & $2.51 \mathrm{a}$ & $12.9 \mathrm{a}$ & $6.48 \mathrm{a}$ & $37.47 \mathrm{~b}$ & $123.58 \mathrm{c}$ & 15.17 \\
\hline Busiyear & Period since establishment (years) ${ }^{\mathrm{z}}$ & $19.62 \mathrm{a}$ & $28.58 \mathrm{~b}$ & $32.00 \mathrm{~b}$ & $36.94 \mathrm{~b}$ & $26.33 \mathrm{ab}$ & 24.64 \\
\hline Peracuse & Acreage used in production $(\%)^{\mathrm{w}}$ & $0.59 \mathrm{a}$ & $0.65 \mathrm{a}$ & $0.58 \mathrm{a}$ & $0.57 \mathrm{a}$ & $0.70 \mathrm{a}$ & 0.61 \\
\hline Laboravail & Perception of labor availability $(\%)^{\mathrm{v}}$ & 0.59 & 0.66 & 0.59 & 0.68 & 0.83 & 0.63 \\
\hline Ltermcap & $\begin{array}{l}\text { Perception of term-term } \\
\text { capital availability }(\%)^{\mathrm{v}}\end{array}$ & 0.53 & 0.78 & 0.77 & 0.89 & 0.83 & 0.65 \\
\hline Corporate & Corporation $(\%)^{\mathrm{v}}$ & 0.09 & 0.51 & 0.64 & 0.47 & 0.58 & 0.29 \\
\hline
\end{tabular}

${ }^{2}$ Significantly different by annual gross sales at $P \leq 0.001$ using analysis of variance (ANOVA).

VValues in the same row with different letters are significantly different by annual gross sales at $P \leq 0.05$ using Scheffe multiple-comparison test.

${ }^{x} 1$ acre $=0.4047$ ha.

"Not significantly different by annual gross sales at $P \leq 0.05$ using ANOVA.

'Significantly different by annual gross sales at $P \leq 0.001$ using Pearson chi-square.

explained $87.5 \%$ of variations in the decisions involving the hiring of 18 - to 39-year-old workers (Table 6). The differences in the decisions involving the employment of workers in the 40to 59-year-old group were explained by $47 \%$ of the independent variables. The empirical results explaining the divergences in hiring 60-year-old and above were excluded in the analysis because only $16.2 \%$ were explained by the independent variables. 
The number of 18- to 39-year-old workers employed was substantially stimulated by the type of operation, period since establishment, annual gross sales, acreage, and availability of labor and capital (Table 6). Larger operations tend to hire more workers from this age group most especially those with annual gross sales above $\$ 2,000,000$. The availability of labor and operating capital encouraged the hiring of more workers from this age group. However, both the nurseryonly and greenhouse-only operations hired fewer 18- to 39-year-old workers than the mixed-nursery-greenhouse operations. Further, the perception that long-term capital was available discouraged the hiring of workers from this age group. On the other hand, no substantial stimulus was prompted by wage rate, mechanization, interview date, and sole proprietorship on the number of workers hired from this age group.

More 40- to 59-year-old workers were hired over time by larger operations that have better access to labor markets. However, fewer workers from this age group were hired due to improved mechanization by operations owned by sole proprietors (Table 6). Neutral impacts were observed from gross wage rate, type of operation, period since establishment, small operations, acreage, and availability of capital.

Formal educational atTainMENT OF WORKERS. The educational attainment of hired farmworkers in U.S. farms was distributed as follows: less than ninth grade $(30 \%), 9-12$ years without diploma (21\%), high school graduate $(28 \%)$, and some college education (21\%) (Kandel, 2008). Survey results revealed that the percent of workers with high school education averaged $48 \%$ of workers employed by participating nurseries and greenhouses (Table 7 ). It was followed by workers with college degrees and above $(23 \%)$, workers with less than high school education $(22 \%)$, and associate degrees $(7 \%)$.

Regression results showed that the hiring of workers with high school education and below was significantly explained by the independent variables included in the models. The number of workers who completed less than high school averaged 2.23 workers per operation (Table 7 ). The empirical model for this educational group explained $62.9 \%$ of the variations in hiring decisions (Table 8 ). The hiring of workers from this group was primarily influenced by annual gross sales. More workers with this educational background were hired by larger operations especially those with more than $\$ 2,000,000$ annual gross sales. The other variable in the model did not have any significant impact on hiring decisions.

The average number of workers who completed high school was 4.31 workers per operation (Table 7). The regression results for this group accounted for $67.5 \%$ of the differences in the hiring decisions (Table 8). More high school graduates were employed by nurseries and greenhouses over time, with higher annual gross sales, and better access to labor markets.
Fewer workers with high school were hired by nursery-only establishments with improved mechanization, less access to long-term capital, and owned by sole proprietors.

The empirical results of the "workers who completed associate degree" and "workers who completed college degree and above" were not reported, because only $24.9 \%$ and $37.75 \%$ of the deviations in the hiring decisions were accounted for by the model, respectively. The number of workers averaged 0.37 worker per operation with associate degree and 1.0 worker per operation with college degree and above.

Gender composition OF WORKERS. The U.S. farms are predominantly manned by male hired farmworkers averaging $81 \%$ in 2009 (Kandel, 2008). The nursery surveys showed that more than two-thirds (69\%) of workers in participating horticulture operations were male (Table 9). As this industry requires significant physical labor, these figures are expected. Many of the female workers in the green industry are placed in positions that include propagation, pruning, and staking/tying.

Regression results indicated that the employment of male and female workers was considerably explained by the variables included in the models. The empirical model for "workers who were male" explained $74.2 \%$ of the variations in hiring decisions (Table 10). The regression results for the "workers who were female" influenced $47.9 \%$ of the differences in the hiring decisions.

Table 5. Age composition of workers employed by randomly selected wholesale nurseries and greenhouses located in eight selected U.S. southern states, which participated in a socioeconomic survey from Dec. 2003 to Nov. 2009 by annual gross sales.

\begin{tabular}{|c|c|c|c|c|c|c|c|}
\hline Variable code & Variable description & $\begin{array}{c}\text { Sales } \\
\text { less than } \\
\$ 250,000 \\
\end{array}$ & $\begin{array}{c}\text { Sales } \\
\$ 250,000- \\
\$ 499,999\end{array}$ & $\begin{array}{c}\text { Sales } \\
\$ 500,000- \\
\$ 999,999\end{array}$ & $\begin{array}{c}\text { Sales } \\
\$ 1,000,000- \\
\$ 1,999,999\end{array}$ & $\begin{array}{c}\text { Sales } \\
\$ 2,000,000 \\
\text { and above }\end{array}$ & $\begin{array}{c}\text { All } \\
\text { operations }\end{array}$ \\
\hline Work1839 & $\begin{array}{l}\text { Workers } 18-39 \text { years old } \\
\quad(\text { no./operation })^{\mathrm{z}}\end{array}$ & $0.94 \mathrm{a}^{\mathrm{y}}$ & $3.36 \mathrm{~b}$ & $6.81 \mathrm{c}$ & $8.94 \mathrm{c}$ & $30.41 \mathrm{~d}$ & 4.45 \\
\hline Work4059 & $\begin{array}{l}\text { Workers } 40-59 \text { years old } \\
\quad(\text { no./operation })^{z}\end{array}$ & $1.37 \mathrm{a}$ & $2.07 \mathrm{a}$ & $2.72 \mathrm{a}$ & $9.89 \mathrm{~b}$ & $11.83 \mathrm{~b}$ & 3.02 \\
\hline Pw1839 & Workers $18-39$ years old $(\%)^{\mathrm{z}}$ & $0.25 \mathrm{a}$ & $0.54 \mathrm{~b}$ & $0.67 \mathrm{~b}$ & $0.54 \mathrm{~b}$ & $0.73 \mathrm{~b}$ & 0.41 \\
\hline Pw4059 & Workers $40-59$ years old $(\%)^{z}$ & $0.62 \mathrm{a}$ & $0.34 \mathrm{~b}$ & $0.26 \mathrm{~b}$ & $0.42 \mathrm{ab}$ & $0.25 \mathrm{~b}$ & 0.50 \\
\hline Pw60up & $\begin{array}{l}\text { Workers } 60 \text { years old } \\
\text { and older }(\%)^{\mathrm{w}}\end{array}$ & $0.11 \mathrm{a}$ & $0.10 \mathrm{a}$ & $0.06 \mathrm{a}$ & $0.02 \mathrm{a}$ & $0.01 \mathrm{a}$ & 0.09 \\
\hline
\end{tabular}

${ }^{\text {z }}$ ignificantly different by annual gross sales at $P \leq 0.001$ using analysis of variance (ANOVA).

VValues in the same row with different letters are significantly different by annual gross sales at $P \leq 0.05$ using Scheffe multiple-comparison test.

${ }^{x}$ Significantly different by annual gross sales at $P \leq 0.01$ using ANOVA.

wot significantly different by annual gross sales at $P \leq 0.05$ using ANOVA. 


\section{Summary and implications}

The survey results among wholesale nursery and greenhouse growers in selected eight southern states revealed some insights into labor hiring decisions in the industry. It must be emphasized that caution must be observed when making generalizations about wholesale nursery and greenhouse operations in the United States in general, and in the southern states, in particular.

Horticulture establishments with higher annual gross sales were more inclined to employ more permanent

Table 6. Factors influencing the decisions to hire workers in nurseries and greenhouses by age groups. The multiple linear regressions used data collected from the socioeconomic survey of randomly selected wholesale nurseries and greenhouses located in eight selected U.S. southern states from Dec. 2003 to Nov. 2009.

\begin{tabular}{|c|c|c|c|c|}
\hline \multirow[b]{2}{*}{ Independent variable } & \multicolumn{2}{|c|}{$\begin{array}{c}\text { Workers } 18-39 \text { years old } \\
\text { (no./operation) }\end{array}$} & \multicolumn{2}{|c|}{$\begin{array}{c}\text { Workers } 40-59 \text { years old } \\
\text { (no./operation) }\end{array}$} \\
\hline & Coefficient & $\mathrm{SE}^{\mathrm{Z}}$ & Coefficient & SE \\
\hline Constant term & $-19.459 \mathrm{NS}$ & 12.378 & $-46.150^{*}$ & 22.374 \\
\hline Deflated gross wage rate $(\$ / \mathrm{h})$ & $0.067 \mathrm{NS}$ & 0.211 & $-0.258 \mathrm{NS}$ & 0.399 \\
\hline Average level of mechanization (\%) & $-0.023 \mathrm{NS}$ & 0.019 & $-0.083^{*}$ & 0.036 \\
\hline Nursery-only operation & $-2.044^{*}$ & 0.807 & $-0.505 \mathrm{NS}$ & 0.699 \\
\hline Greenhouse-only operation & $-1.758 * *$ & 0.618 & $1.183 \mathrm{NS}$ & 0.732 \\
\hline Period since establishment (years) & $-0.021^{*}$ & 0.011 & $0.052 \mathrm{NS}$ & 0.029 \\
\hline Interview date & $0.001 \mathrm{NS}$ & 0.000 & $0.001 *$ & 0.001 \\
\hline Annual sales $\$ 250,000-\$ 499,999$ & $2.671 * * *$ & 0.509 & $1.131 \mathrm{NS}$ & 0.597 \\
\hline Annual sales $\$ 500,000-\$ 999,999$ & $5.965 * * *$ & 0.865 & 0.683 Ns & 0.982 \\
\hline Annual sales $\$ 1,000,000-\$ 1,999,999$ & $8.319 * * *$ & 1.046 & $8.809^{* *}$ & 2.675 \\
\hline Annual sales $\$ 2,000,000$ and above & $29.580 * * *$ & 3.585 & $11.793^{* *}$ & 3.374 \\
\hline Acreage under production (acres) $)^{y}$ & $-0.007 \mathrm{NS}$ & 0.016 & $-0.001 \mathrm{NS}$ & 0.011 \\
\hline Area used in production (\%) & $0.023^{* *}$ & 0.008 & $-0.019 \mathrm{NS}$ & 0.012 \\
\hline Availability of labor & $1.309^{*}$ & 0.517 & $1.663^{*}$ & 0.751 \\
\hline Availability of long-term capital & $-1.626^{\star}$ & 0.562 & $-0.614 \mathrm{Ns}$ & 0.795 \\
\hline Availability of operating capital & $0.886^{* *}$ & 0.599 & $0.930 \mathrm{Ns}$ & 0.901 \\
\hline Sole proprietorship & $-0.303 \mathrm{NS}$ & 0.431 & $-1.981 *$ & 0.849 \\
\hline Included nurseries and greenhouses (no.) & 174 & & 174 & \\
\hline R-squared & 0.875 & & 0.470 & \\
\hline F statistic & 46.420 *** & & $3.530 * * *$ & \\
\hline
\end{tabular}

${ }^{2}$ Robust SE (accurate assessments of the sample-to-sample variability of the parameter estimates are achieved with the use of the robust variance procedure).

yl acre $=0.4047$ ha.

${ }^{*},{ }^{* *},{ }^{* *}$ Statistically significant at $P \leq 0.05,0.01$, or 0.001 using $\mathrm{T}$ value or $\mathrm{F}$ statistic; ${ }^{\mathrm{Ns}}$ Not statistically significant at $P \leq 0.05$ using T value or $\mathrm{F}$ statistic.

Table 7. Formal educational attainment of workers employed by randomly selected wholesale nurseries and greenhouses located in eight selected U.S. southern states, which participated in a socioeconomic survey from Dec. 2003 to Nov. 2009 by annual gross sales.

\begin{tabular}{|c|c|c|c|c|c|c|c|}
\hline $\begin{array}{l}\text { Variable } \\
\text { code }\end{array}$ & Variable description & $\begin{array}{c}\text { Sales } \\
\text { less than } \\
\$ 250,000 \\
\end{array}$ & $\begin{array}{c}\text { Sales } \\
\$ 250,000- \\
\$ 499,999 \\
\end{array}$ & $\begin{array}{c}\text { Sales } \\
\$ 500,000- \\
\$ 999,999 \\
\end{array}$ & $\begin{array}{c}\text { Sales } \\
\$ 1,000,000- \\
\$ 1,999,999\end{array}$ & $\begin{array}{c}\text { Sales } \\
\$ 2,000,000 \\
\text { and above }\end{array}$ & $\begin{array}{c}\text { All } \\
\text { operations } \\
\end{array}$ \\
\hline Worklths & $\begin{array}{l}\text { Workers who completed less than } \\
\text { high school (no./operation })^{z}\end{array}$ & $0.46 \mathrm{a}^{\mathrm{y}}$ & $1.75 \mathrm{~b}$ & $4.22 \mathrm{c}$ & $4.15 \mathrm{c}$ & $14.25 \mathrm{~d}$ & 2.23 \\
\hline Workwchs & $\begin{array}{l}\text { Workers who completed high } \\
\text { school (no./operation })^{\mathrm{z}}\end{array}$ & $1.35 \mathrm{a}$ & $2.82 \mathrm{a}$ & $4.81 \mathrm{a}$ & $11.52 \mathrm{~b}$ & $25.16 \mathrm{c}$ & 4.31 \\
\hline Workcolladv & $\begin{array}{l}\text { Workers who completed college } \\
\text { degree and above (no./operation })^{\mathrm{z}}\end{array}$ & $0.61 \mathrm{a}$ & $1.04 \mathrm{a}$ & $1.00 \mathrm{a}$ & $2.84 \mathrm{~b}$ & $1.75 \mathrm{~b}$ & 1.00 \\
\hline Pwlths & $\begin{array}{l}\text { Workers who completed less than } \\
\text { high school }(\%)^{\mathrm{z}}\end{array}$ & $0.13 \mathrm{a}$ & $0.28 \mathrm{ab}$ & $0.40 \mathrm{~b}$ & $0.28 \mathrm{ab}$ & $0.35 \mathrm{ab}$ & 0.22 \\
\hline Pwchs & $\begin{array}{l}\text { Workers who completed high } \\
\text { school }(\%)^{\mathrm{w}}\end{array}$ & $0.48 \mathrm{a}$ & $0.43 \mathrm{a}$ & $0.46 \mathrm{a}$ & $0.52 \mathrm{a}$ & $0.56 \mathrm{a}$ & 0.48 \\
\hline
\end{tabular}

${ }^{\text {z }}$ Significantly different by annual gross sales at $P \leq 0.001$ using analysis of variance (ANOVA).

Values in the same row with different letters are significantly different by annual gross sales at $P \leq 0.05$ using Scheffe multiple-comparison test.

${ }^{x}$ Significantly different by annual gross sales at $P \leq 0.05$ using ANOVA.

wNot significantly different by annual gross sales at $P \leq 0.05$ using ANOVA. 
workers. On per acre under cultivation basis, however, larger horticulture firms seemed to have employed fewer permanent workers. This latter observation indicated that permanent workers in larger establishments are relatively more efficient or have higher productivity.

Horticulture firms with higher annual gross sales were more inclined to retain more part-time workers. It appeared that the average labor efficiency or productivity of part-time workers per acre was the same across the different sizes of horticultural firms.
Over time, mixed-nursery-greenhouse operations with higher annual gross sales and better access to operating capital hired more Caucasian workers. Horticultural operations that have been in business not very long, operated larger acreage, and have large annual gross sales hired relatively more Hispanic workers during the entire period.

Large mixed-nurseries and greenhouses not operating very long in large acreage and have better access to labor and operating capital preferred to employ more 18- to 39-year-old workers. Multiple ownership, less mechanized, very large horticultural operations with better access to labor market decided to hire more 40 - to 59-year-old workers during the entire period.

Large horticulture establishments with more acreage under cultivation were hiring more workers who completed less than high school. Multipleowned, older, and less mechanized mixed-type operations with enhanced access to labor market chose to employ workers who completed high school.

Multiple-ownership horticulture operations with very high annual gross sales hired relatively more male workers during the entire period. Large

Table 8. Factors influencing the decisions to hire workers in nurseries and greenhouses by formal education attainment. The multiple linear regressions used data collected from the socioeconomic survey of randomly selected wholesale nurseries and greenhouses located in eight selected U.S. southern states from Dec. 2003 to Nov. 2009.

\begin{tabular}{|c|c|c|c|c|}
\hline \multirow[b]{2}{*}{ Independent variable } & \multicolumn{2}{|c|}{$\begin{array}{l}\text { Workers who completed less than } \\
\text { high school (no./operation) }\end{array}$} & \multicolumn{2}{|c|}{$\begin{array}{c}\text { Workers who completed } \\
\text { high school (no./operation) }\end{array}$} \\
\hline & Coefficient & $\mathrm{SE}^{\mathrm{z}}$ & Coefficient & SE \\
\hline Deflated gross wage rate $(\$ / \mathrm{h})$ & $-0.109 \mathrm{NS}$ & 0.309 & $-0.409 \mathrm{NS}$ & 0.424 \\
\hline Average level of mechanization (\%) & $-0.018 \mathrm{NS}$ & 00.26 & $-0.069^{*}$ & 0.034 \\
\hline Nursery-only operation & $1.051 \mathrm{NS}$ & 0.624 & $-3.489 * *$ & 1.046 \\
\hline Interview date & $-0.001 \mathrm{NS}$ & 0.00 & $0.002 * *$ & 0.001 \\
\hline Annual sales $\$ 250,000-\$ 499,999$ & $1.277^{* *}$ & 0.439 & $2.153^{* *}$ & 0.737 \\
\hline Annual sales $\$ 500,000-\$ 999,999$ & $4.578 * * *$ & 0.859 & $1.969 \mathrm{NS}$ & 1.242 \\
\hline Annual sales $\$ 1,000,000-\$ 1,999,999$ & $2.968^{*}$ & 1.387 & $10.998 * * *$ & 2.592 \\
\hline Annual sales $\$ 2,000,000$ and above & $10.840 * * *$ & 3.202 & $28.010 * * *$ & 4.442 \\
\hline Availability of operating capital & $-1.283 \mathrm{NS}$ & 0.742 & $1.809 \mathrm{NS}$ & 1.124 \\
\hline Sole proprietorship & $-0.478 \mathrm{NS}$ & 0.408 & $-1.964^{*}$ & 0.904 \\
\hline Included nurseries and greenhouses (no.) & 174 & & 173 & \\
\hline R-squared & 0.629 & & 0.675 & \\
\hline F statistic & $28.390 * * *$ & & $9.06 * * *$ & \\
\hline
\end{tabular}

${ }^{2}$ Robust SE (accurate assessments of the sample-to-sample variability of the parameter estimates are achieved with the use of the robust variance procedure).

yl acre $=0.4047$ ha .

${ }^{*},{ }^{* *},{ }^{* *}$ Statistically significant at $P \leq 0.05,0.01$, or 0.001 using $\mathrm{T}$ value or $\mathrm{F}$ statistic; ${ }^{\mathrm{N}}$ Not statistically significant at $P \leq 0.05$ using T value or F statistic.

Table 9. Gender composition of workers employed by randomly selected wholesale nurseries and greenhouses located in eight selected U.S. southern states which participated in a socioeconomic survey from Dec. 2003 to Nov. 2009 by annual gross sales.

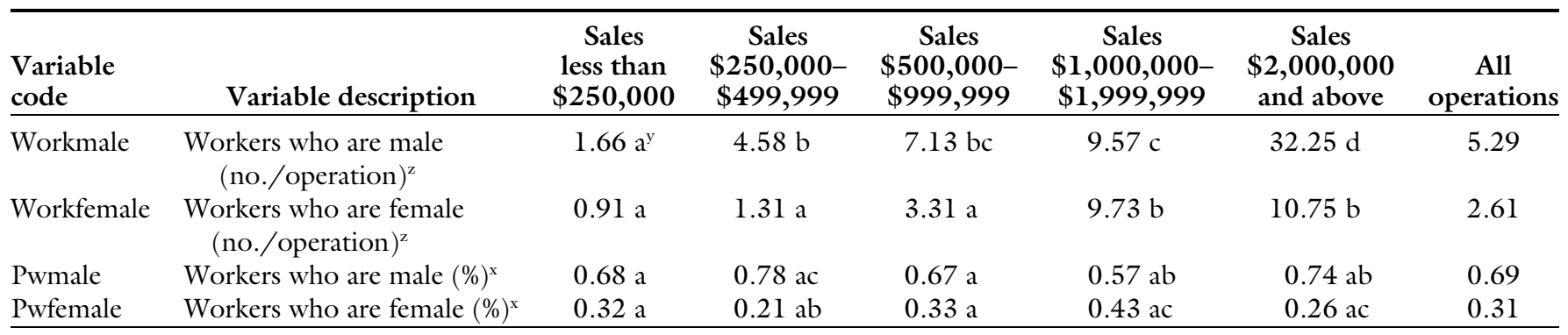

${ }^{z}$ Significantly different by annual gross sales at $P \leq 0.001$ using analysis of variance (ANOVA).

Values in the same row with different letters are significantly different by annual gross sales at $P \leq 0.05$ using Scheffe multiple-comparison test.

${ }^{x}$ Significantly different by annual gross sales at $P \leq 0.05$ using ANOVA. 
Table 10. Factors influencing the decisions to hire workers in nurseries and greenhouses by gender. The multiple linear regressions used data collected from the socioeconomic survey of randomly selected wholesale nurseries and greenhouses located in eight selected U.S. southern states from Dec. 2003 to Nov. 2009.

\begin{tabular}{|c|c|c|c|c|}
\hline \multirow[b]{2}{*}{ Independent variable } & \multicolumn{2}{|c|}{ Workers who are male (no./operation) } & \multicolumn{2}{|c|}{ Workers who are female (no./operation) } \\
\hline & Coefficient & $\mathrm{SE}^{\mathrm{z}}$ & Coefficient & SE \\
\hline Constant term & $-50.609^{*}$ & 20.570 & $-23.315 \mathrm{NS}$ & 19.468 \\
\hline Average level of mechanization (\%) & $-0.040 \mathrm{NS}$ & 0.027 & $-0.052 \mathrm{NS}$ & 0.033 \\
\hline Nursery-only operation & $-1.427 \mathrm{Ns}$ & 0.966 & $-1.420 \mathrm{NS}$ & 0.721 \\
\hline Greenhouse-only operation & $-0.078 \mathrm{NS}$ & 0.838 & $-0.841 \mathrm{NS}$ & 0.676 \\
\hline Annual sales $\$ 250,000-\$ 499,999$ & $3.000 * * *$ & 0.669 & $0.721 \mathrm{NS}$ & 0.539 \\
\hline Annual sales $\$ 500,000-\$ 999,999$ & $4.907 * * *$ & 1.247 & $2.053 * *$ & 0.766 \\
\hline Annual sales $\$ 1,000,000-\$ 1,999,999$ & $7.333 * * *$ & 1.222 & $9.635 * * *$ & 2.623 \\
\hline Annual sales $\$ 2,000,000$ and above & $28.821 * * *$ & 5.771 & $12.743 * * *$ & 3.509 \\
\hline Acreage under production $(\text { acres })^{\mathrm{y}}$ & $0.016 \mathrm{NS}$ & 0.019 & $-0.027^{*}$ & 0.011 \\
\hline Sole proprietorship & $-1.286^{*}$ & 0.645 & $-1.121 \mathrm{NS}$ & 0.778 \\
\hline Included nurseries and greenhouses (no.) & 174 & & 174 & \\
\hline R-squared & 0.742 & & 0.479 & \\
\hline F statistic & $12.830 * * *$ & & $4.19 * * *$ & \\
\hline
\end{tabular}

${ }^{2}$ Robust SE (accurate assessments of the sample-to-sample variability of the parameter estimates are achieved with the use of the robust variance procedure). y 1 acre $=0.4047$ ha.

${ }^{*},{ }^{* *},{ }^{* *}$ Statistically significant at $P \leq 0.05,0.01$, or 0.001 using $\mathrm{T}$ value or $\mathrm{F}$ statistic; ${ }^{\mathrm{N}}$ Not statistically significant at $P \leq 0.05$ using $\mathrm{T}$ value or $\mathrm{F}$ statistic.

nurseries and greenhouses with lesser acreage under cultivation tend to hire more female workers.

\section{Literature cited}

Alabama Department of Agriculture and Industries. 2004. Certified nurseries. Alabama Dept. Agr. Ind., Bureau Plant Ind., Montgomery, AL.

Bartel, A. and F. Lichtenberg. 1987. The comparative advantage of educated workers in implementing new technology. Rev. Econ. Stat. 69:1-11.

Bellenger, M., D. Fields, K. Tilt, and D. Hite. 2008. Producer preferences for migrant labor and the wage, hours, and gross sales effects in Alabama's horticulture industry. HortTechnology 18:301-307.

Buccola, S., C. Li, and J. Reimer. 2011. Minimum wages, immigration control, and agricultural labor supply. Amer. J. Agr. Econ. 94:464-470.

Bureau of Labor Statistics. 2012. Occupational outlook handbook: Agricultural workers. 9 May 2012. <http://www.bls. gov/oco/ocos349.htm>.

Coker, R.Y., B.C. Posadas, S.A. Langlois, P.R. Knight, and C.H. Coker. 2010. Current mechanization systems among nurseries and mixed operations. Mississippi. Agr. For. Expt. Sta. Bul. 1189.
Florida Department of Agriculture and Consumer Services. 2005. Certified nursery and stock dealer list. Florida Dept. Agr. Consumer Serv., Bureau Plant Ind., Tallahassee, FL.

Gabbard, S.M. and J.M. Perloff. 1997. The effects of pay and work conditions on farmworker retention. Ind. Relat. 36: 474-488.

Georgia Department of Agriculture. 2007. Live plant licenses. Georgia Dept. Agr., Bureau Plant Ind., Atlanta, GA.

Hodges, A.W., C.R. Hall, and M.A. Palma. 2011. Economic contributions of the green industry in the United States, 2007. Southern Coop. Series Bul. No. 413. 10 Dec. 2011 . <http://www.fred.ifas. edu/economic-impact/pdf/US-greenindustry-in-2007.pdf $>$.

Holt, J.S., S.M. Knebel, R. McElroy, and D.W. Sturt. 1970. Impact of the industrialization of the hired farm work force upon the agricultural economy. Amer. J. Agr. Econ. 52:780-786.

Jones, P. 2001. Are educated workers really more productive? J. Dev. Econ. 64:57-79.

Kandel, W. 2008. Profile of hired farmworkers: A 2008 update. U.S. Dept. Agr., Econ. Res. Serv., Econ. Res. Rpt. No. 60. 17 May 2013. <http://www.ers.usda. gov/media/205619/err60_1_.pdf>.
Louisiana Department of Agriculture and Forestry. 2003. Nursery certificate listing. Louisiana Dept. Agr. For., Horticulture Quarantine Prog., Baton Rouge, LA.

Mathers, H.M., A.A. Acuna, D.R. Long, B.K. Behe, A.W. Hodges, J.J. Haydu, U.K. Schuch, S. Barton, J.H. Dennis, B.K. Maynard, C.H. Hall, R. McNeil, and T. Archer. 2010. Nursery worker turnover and language proficiency. HortTechnology 45:71-77.

Mississippi Department of Agriculture and Commerce. 2003. Directory of Mississippi certified nurseries and nursery dealers. Mississippi Dept. Agr. Commerce, Bureau Plant Ind., Mississippi State, MS.

Mitra, A. 2003. Establishment size, employment, and the gender wage gap. J. Socio-Econ. 32:317-330.

North Carolina Department of Agriculture and Consumer Services. 2008. Directory of certified nurseries and plant collectors. North Carolina Dept. Agr. Consumer Serv., Plant Ind. Div., Raleigh, NC.

$\mathrm{O}^{*} \mathrm{Net}$ Online. 2013. Summary report for: 45-2092.01 - Nursery workers. 29 May 2013. <http://www.onetonline.org/ link/summary/45-2092.01 >.

Perloff, J.M., L. Lynch, and S.M. Gabbard. 1998. Migration of seasonal agricultural 
workers. Amer. J. Agr. Econ. 80:154164.

Posadas, B.C. 2012. Economic impacts of mechanization or automation on horticulture production firms sales, employment, and workers' earnings, safety, and retention. HortTechnology 22:388-401.

Posadas, B.C., G.B. Fain, C.H. Coker, P.R. Knight, C.D. Veal, and R.Y. Coker. 2004. Socioeconomic survey of nursery automation. Proc. Southern Nursery Assn. Res. Conf. 49:306-309.

Posadas, B.C., P.R. Knight, C.H. Coker, R.Y. Coker, S.A. Langlois, and C.D. Veal. 2005. Levels of technology adoption among horticulture firms in the northern Gulf of Mexico. Proc. Southern Nursery Assn. Res. Conf. 50:365-368.
Posadas, B.C., P.R. Knight, C.H. Coker, R.Y. Coker, and S.A. Langlois. 2008. Socioeconomic impact of automation on horticulture production firms in the northern Gulf of Mexico. HortTechnology 18:697-704.

Posadas, B.C., P.R. Knight, C.H. Coker, R.Y. Coker, and S.A. Langlois. 2010a. Socioeconomic characteristics of workers and working conditions in nurseries and greenhouses in the northern Gulf of Mexico states. Mississippi Agr. For. Expt. Sta. Bul. 1182

Posadas, B.C., P.R. Knight, C.H. Coker, R.Y. Coker, and S.A. Langlois. 2010b. Operational characteristics of nurseries and greenhouses in the northern Gulf of Mexico states. Mississippi Agr. For. Expt. Sta. Bul. 1184.
Regelbrugge, C.J. 2007. American agriculture and immigration reform: An industry perspective. 5 May 2008. <http:// www.usda.gov / oce / / / forum / 2007\%20Speeches/PDF\%20speeches/ CRegelbrugge.pdf $>$.

Rogers, W.H. 1993. Regression standard errors in clustered samples. Stata Tech. Bull. 13:19-23. (reprinted in Stata Tech. Bul. Reprints 3:88-94).

South Carolina Department of Agriculture. 2006. Nursery directory. South Carolina Dept. Agr. Columbia, SC.

Tennessee Nursery and Landscape Association. 2006. Nursery buyers guide. McMinnville, TN.

Williams, R.L. 2000. A note on robust variance estimation for clustered-correlated data. Biometrics 56:645-646. 